\title{
Ventricular assist device implantation in grown-up congenital heart disease patients
}

\author{
O Szárszoi ${ }^{*}$, J Pirk' , J Maly ${ }^{1}$, M Urban', D Turek , H Riha², T Kotulak², Z Dorazilova ${ }^{3}$, I Netuka \\ From 23rd World Congress of the World Society of Cardio-Thoracic Surgeons \\ Split, Croatia. 12-15 September 2013
}

\section{Introduction}

Advances in palliation of congenital heart disease have resulted in improved survival to adulthood. Nevertheless many of these patients ultimately develop end-stage heart failure requiring heart transplantation. Implantation of ventricular assist device is life-saving option for such patients, allowing for bridge to transplant. In the present study we describe our experience with implantation of ventricular assist device Heart Mate II as bridge to transplant in adult patients with congenital heart disease.

\section{Methods}

Of 104 patients who underwent ventricular assist device implantation at our institute from December 2007 to April 2013, 8 patients ranging in age from 14 to 40 years $(6 \mathrm{male})$, in the end-stage of the heart failure were diagnosed to have adult congenital heart disease. We retrospectively reviewed the clinical data, operative and postoperative courses of these patients.

\section{Results}

Anatomical diagnoses were transposition of the great arteries in 6 patients ( 5 patients have Mustard procedure as a child and one patient has congenitally corrected transposition of the great arteries), single-ventricle defect in 1 patient and coarctation of aorta in 1 patient.

Despite high risk heart surgery, implantation of ventricular assist device was performed in all patients with zero perioperative mortality. Overall mechanical support time was $232 \pm 116$ days (mean \pm SD; range $34-349$ days). Four patients were successfully bridged to heart transplantation, three patients unfortunately suffered from thromboembolic and septic complications and had died, and one is still waiting for heart transplant.

\footnotetext{
* Correspondence: onsz@ikem.cz

'Department of Cardiac Surgery, Institute for Clinical and Experimental Medicine, Prague, Czech Republic

Full list of author information is available at the end of the article
}

\section{Conclusion}

Adults with congenital heart defects and congestive heart failure are a challenging population because of their complex anatomy, prior surgical palliation, and hemodynamic status. We conclude from our experience that ventricular assist device surgery can be safely performed in these high risk patients.

Study was supported by Grant IGA MZ NT/11269-5.

\section{Authors' details}

'Department of Cardiac Surgery, Institute for Clinical and Experimental Medicine, Prague, Czech Republic. 'Department of Cardiac Anaesthesiology, Institute for Clinical and Experimental Medicine, Prague, Czech Republic. ${ }^{3}$ Department of Cardiology, Institute for Clinical and Experimental Medicine, Prague, Czech Republic.

Published: 11 September 2013

doi:10.1186/1749-8090-8-S1-065

Cite this article as: Szárszoi et al:: Ventricular assist device implantation in grown-up congenital heart disease patients. Journal of Cardiothoracic Surgery 2013 8(Suppl 1):065.

Submit your next manuscript to BioMed Central and take full advantage of:

- Convenient online submission

- Thorough peer review

- No space constraints or color figure charges

- Immediate publication on acceptance

- Inclusion in PubMed, CAS, Scopus and Google Scholar

- Research which is freely available for redistribution

Submit your manuscript at www.biomedcentral.com/submit
() Biomed Central

\section{() Biomed Central}

